\title{
Маніпуляційні технології в політичних процесах: термінологічний інструментарій
}

\author{
Костельнюк М.М., Чорноморський національний університет імені П. Могили
}

Здійснено термінологічний аналіз понять «маніпуляція», «маніпулювання», визначено мету маніпулювання як технології впливу на політичний процес, а також спробу розкрити об'єктивні передумови виникнення феномену маніпуляції в сучасній політиці. Охарактеризовано маніпулювання як важливий чинник сучасного політичного процесу. Проаналізовано основні етапи підготовки й реалізації маніпулювання та визначено основні функції, які виконує маніпулювання як специфічна форма політичного впливу. Висвітлено концептуальні підходи до розуміння сутності проблеми політичного маніпулювання. Наголошено, що вивчення та використання механізмів маніпулювання відкриває можливості для впливу на велику кількість людей і дає змогу досягати поставленої мети. Проаналізовано найбільш поширені прийоми політичних маніпуляцій свідомістю виборців. Здійснено аналіз місця та ролі маніпулятивних технологій у контексті політичних виборчих технологій. Досліджено методи впливу політичного маніпулювання на суспільну підтримку прийняття політико-управлінських рішень та умови й механізми маніпуляції свідомістю в політичному процесі. Встановлено фактори, що створюють умови для існування політичних маніпуляцій. Визначено шляхи й методи вивчення та врахування громадської думки, обмежень впливу політичних маніпулювань.

Ключові слова: вплив; маніпулювання; маніпуляція; переконання; політичний вплив; політичне маніпулювання; прийоми політичних маніпуляцій; засоби масової інформації; виборча кампанія

\section{Manipulation technologies in political processes: terminological tools}

\section{Kostelnuk M.M., P.Mohla Black Sea National University}

The terminology analysis of the concepts of «manipulation», «manipulation» is carried out, the purpose of manipulation as a technology of influence on the political process is determined, as well as an attempt to reveal the objective preconditions for the emergence of the phenomenon of manipulation in modern politics. It was discovered that manipulation is the programming of human behavior with the help of spiritual and psychological influence on them. This influence is aimed at the mental structure of a person, carried out hidden and has the task of changing the thoughts and goals of people in the direction required by the authorities or a certain political leader. Manipulation is described as an important factor in the modern political process. The main stages of the preparation and implementation of manipulation are analyzed and the main functions that perform manipulation as a specific form of political influence are defined. It was noted that political consciousness is an indirect reflection of the political life of society, the essence of which is the problem of power, the formation, development and satisfaction of the interests and needs of political actors. The conceptual approaches to understanding the essence of the problem of political manipulation are highlighted. It is emphasized that studying and using mechanisms of manipulation opens opportunities for influencing a large number of people and allows them to achieve their goal. The most common methods of political manipulation by the consciousness of voters are analyzed. The analysis of the place and role of manipulative technologies in the context of political electoral technologies is analyzed. The methods of the influence of political manipulation on the public support of the adoption of political and managerial decisions and the conditions and mechanisms of manipulation of consciousness in the political process are explored. Established factors that create conditions for the existence of political manipulation. The ways and methods of studying and taking into account public opinion, limitations of influence of political manipulation are determined. The types of processes of manipulation of mass consciousness are analyzed. To their number include: myth-making; the formation of a «picture of the world» in the mass consciousness; formation of ideology; development of technologies for information warfare; use of systems of remote distortion and destruction of information, influence through multimedia sites; development of processes of psychological warfare; manipulation with the use of psycho technologies; semantic manipulation and use of rumors. Different forms, methods and types of manipulation through the mass media are analyzed - press conference, conference, presentation, press tour, publications in mass media (interesting articles, case studies, review articles, interviews), dissemination of rumors, influence television and radio, Internet.

Keywords: influence; manipulation; persuasion; political influence; political manipulation; techniques of political manipulation; mass media; election campaign 


\title{
Манипуляционныетехнологии вполитическихпроцессах: терминологический инструментарий
}

\author{
Костельнюк М.М., Черноморский национальный университет имени Петра Могилы
}

Осуществлен терминологический анализ понятий «манипуляция», «манипулирование», определены цели манипулирования как технологии влияния на политический процесс, а также попытка раскрыть объективные предпосылки возникновения феномена манипуляции в современной политике. Охарактеризовано манипулирование как важный фактор современного политического процесса. Проанализированы основные этапы подготовки и реализации манипулирования и определены основные функции, которые выполняет манипулирование как специфическая форма политического влияния. Освещены концептуальные подходы к пониманию сущности проблемы политического манипулирования. Отмечено, что изучение и использование механизмов манипулирования открывает возможности для воздействия на большое количество людей и позволяет достигать поставленной цели. Проанализированы наиболее распространенные приемы политических манипуляций сознанием избирателей. Осуществлен анализ места и роли манипулятивных технологий в контексте политических избирательных технологий. Исследованы методы воздействия политического манипулирования на общественную поддержку принятия политико-управленческих решений и условия и механизмы манипуляции сознанием в политическом процессе. Установлены факторы, создающие условия для существования политических манипуляций. Определены пути и методы изучения и учета общественного мнения, ограничений влияния политических манипуляций.

Ключевые слова: воздействие; манипулирования; манипуляция; убеждения; политическое влияние; политическое манипулирование; приемы политических манипуляций; средства массовой информации; избирательная кампания

\section{Постановка проблеми.}

3 моменту проголошення незалежності та переходу України на демократичний шлях розвитку суб'єкти політики, а саме засоби масової інформації, держава та політичні партії, наряду з інформуванням, просвітництвом, залученням громадян до політичного процесу, все активніше застосовують методи та технології прихованого управління масовою політичною свідомістю і поведінкою громадян. До того ж на сьогодні постає актуальною проблема реалізації основного принципу демократичного суспільства - виборчого процесу. 3 розвитком виборчого законодавства та інституту виборів відповідно розвивається коло застосування методів систематичного впливу на перебіг та результати волевиявлення громадян. У науковій літературі це отримало назву політичні технології, а особливе місце серед них посідають технологій емоційного та психологічного пливу на виборців, що у свою чергу отримало назву маніпулятивні технології.

\section{Аналіз досліджень і публікацій.}

Роль та значення політичних технологій, політичного маніпулювання, впливу політичної реклами досліджуються вже протягом тривалого часу. Зокрема, проблеми політичного маніпулювання та різноманітні сторони механізмів програмування поведінки висвітлюють у своїх працях багато зарубіжних науковців: X. Аренд, Р. Баркер, Л. Бенет, Р. Даль, Р. Дворкін, М. Доган, А. Грамші, Д. Істон, С. Кара-Мурза, М. Кастельс,
Ж.-Л. Кермонн, М. Куаклі, Г. Лассвелл, Л. Лі Кейд, Дж. Лінц, У. Ліппман, С. Ліпсет, Г. Лебон, Т. Лукман, Н. Луман, Г. Мазолені, Б. Макнейр, П. Манчіні, В. Мальцев, К. Меєр, С. Московічі, Е. Ноель-Нойман, П. Норріс, К. Оффе, Т. Парсонс, А. Пшеворскі, Дж. Сарторі, Е. Семпсон, М. Спілмен, Р. Фішер.

Серед українських науковців, що займаються емпіричними електоральними дослідженнями, зокрема вивченням їх маніпулятивної складової, можна назвати: О. Бойка, В. Бабкіну, О. Балакірєву, В. Бебика, I. Бекешкину, С. Богомолова, М. Поповича, В. Ткаченка, А. Полторака. Маніпулятивні технології в електоральному процесі транзитивних суспільств вивчають А. Балашов, О. Валевський, Д. Видрін, І. Жданов, О. Заярна, О. Кордун, Р. Павленко, В. Лісничий, М. Побокін, Ю. Сурмін, Д. Наріжний, Ю. Яновська тощо.

\section{Мета дослідження.}

Метою статті $є$ комплексний науковий політологічний аналіз дефініції «маніпуляційні технології в політичних процесах», зокрема висвітлення сутності поняття політичного маніпулювання, методів та технологій маніпуляційного впливу, який використовується в сучасних політичних процесах із метою маніпуляції масовою свідомістю.

\section{Виклад основного матеріалу.}

На сьогоднішній день найбільш поширеною стає така форма впливу на свідомість громадян, як маніпулювання. Безперечно, на сьогодні існує велика кількість різних визначень того, що 
розуміють під терміном «маніпуляція». Зокрема, маніпуляцію визначають як: психологічний вплив на ту чи іншу людину, який не завжди людиною усвідомлюється, при цьому змушує ії діяти відповідно до цілей маніпулятора; особливий вплив на підсвідомість людини (на почуття, емоції, переживання) задля програмування мотиву людини до співпраці; приховане управління людиною всупереч іiі волі, яке приносить ініціаторові односторонні переваги.

Оксфордський тлумачний словник англійської мови трактує маніпуляцію як «акт впливу на людей або керування ними зі спритністю, особливо зі зневажливим підтекстом, як приховане керування чи обробка». Відтак, основа маніпуляції - експлуатація різних емоцій людини.

Отже, систематизуючи погляди різних науковців, можна визначити дефініцію «маніпуляція» як прихований психологічний особливий спосіб управління людьми та їхньою поведінкою (спрямований на неявне спонукання інших (іншого) до виконання визначених маніпулятором дій).

Основними причинами маніпуляцій є: вічний внутрішній конфлікт людини між іiі прагненням до незалежності і самостійності, 3 одного боку, i бажанням знайти опору в своєму оточенні, - 3 іншого (Ф. Перлз); усвідомлюючи умови свого існування в світі - свою «екзистенційну ситуацію», - людина відчуває себе безпорадною (Д. Бюдженталь); страх замученості, який є одним з основних людських страхів. Виходячи 3 цього, маніпулятора можна визначити як людину, яка намагається уникнути близькості і залученості у відносини 3 іншими людьми, і тому взаємодіє $з$ ними за допомогою певних ритуалів (В. Глассера).

Визначимо чотири типи маніпулятивних схем - поведінковий або ігровий стереотип, а саме: активний маніпулятор (керує іншими за допомогою активних методів, не демонструє свою слабкість у стосунках, грає роль людини повної сил, використовуючи про цьому своє соціальне становище, а також застосовує систему прав і обов'язків, наказів і прохань тощо); пасивний маніпулятор (прикидається безпомічним і грає роль «пригнобленого», перемагає своєю млявістю і пасивністю, дозволяючи працювати за себе); маніпулятор, який змагається (ставиться до життя як до стану, що потребує постійної пильності, оскільки тут можна виграти або програти. Така людина коливається між методами «пригноблювача» і «пригнобленого», тому $є$ середньою ланкою між активним i пасивним маніпулятором); байдужий маніпулятор (намагається відійти від контактів, вдає що йому байдуже, однак насправді його поведінка пов'язана 3 можливістю обіграти партнера).

Безперечно, стереотипи поведінки виступають однією 3 передумов, основ, на якій організовується і здійснюється маніпуляція свідомістю людини. Стереотипність реагування людини - це іiі схильність у схожих ситуаціях діяти схожим чином, а то і аналогічно, як це було в попередніх подібних ситуаціях. Маніпулятори не обмежуються використанням лише наявних стереотипів поведінки людей. Навпаки, приймають заходи для того, щоб сформувати такі стереотипи поведінки (реагування) людей, при цьому - масові, щоб нові стереотипи краще відповідали цілям і завданням маніпулятора.

Таким чином, на наше переконання, маніпуляція - це програмування поведінки людей за допомогою духовного, психологічного впливу на них. Цей вплив спрямований на психічні структури людини, здійснюється приховано і має за завдання змінити думки і мету людей у напрямку, потрібному владі чи певному політичному лідеру.

У політологічному дискурсі нині утвердилася така інтерпретація категорії «політична маніпуляція» - система засобів ідеологічного і духовно-психологічного впливу на масову свідомість 3 метою нав'язування певних ідей, цінностей. Це цілеспрямований вплив на громадську думку та політичну поведінку задля спрямування їх у заданому напрямку.

У цілому можна вважати маніпулювання способом психологічного впливу, котрий спрямований на зміну напряму активності електорату, його ідей, думок, поглядів та іншого.

На сучасному етапі розвитку суспільства маніпуляція свідомістю може розглядатися як своєрідне панування над духовним станом людей, управління їхньою поведінкою шляхом нав'язування їм ідей, установок, мотивів, стереотипів поведінки, вигідних суб'єкту впливу.

У контексті розгляду даної проблематики, принагідно зауважимо, що політична свідомість - це опосередковане відображення політичного життя суспільства, сутністю якого є проблеми влади, формування, розвиток та задоволення інтересів та потреб політичних суб'єктів.

Необхідно окремо наголосити на тому, що основні засоби маніпу ᄀляції суспільною свідомістю $€$ : мовні (використання певних штампів, термінів, ідеологічних та політичних кліше); немовні (блокування чи затримання «невигідної» інформації, викладання інформації у сприятливому для себе контексті); активні (насадження стереотипів і цінностей); пасивні (фрагментарність інформації). 
Найчастіше об'єктом маніпуляції стає масова політична свідомість буденно-емпіричного рівня. Як типові ознаки цього виду свідомості можна виділити: статистичність, безсистемність, однобічність розвитку, стереотипність мислення, міфологізацію свідомості, ситуативність, монологічність суджень, нездатність до діалогу. Саме в ній закладено найбільше ірраціональних елементів, що робить їі найбільш схильною до маніпулятивних впливів. Тому раціональні методи діють лише на раціональну частину суспільства, а ірраціональні - значною мірою на все суспільство в цілому ось це одна 3 найважливіших причин маніпуляції масовою свідомістю, і маніпуляції як суспільного феномену взагалі.

Розрізняють певні види процесів маніпулювання масовою свідомістю. До їхнього числа віднесемо: міфотворчість; формування «картини світу» у масовій свідомості; формування ідеології; розробка технологій ведення інформаційної війни; використання систем дистанційного перекручування $\mathrm{i}$ знищення інформації, вплив через мультимедійні сайти; розробка процесів психологічної війни; маніпуляція із застосуванням психотехнологій; семантичне маніпулювання і використання чуток.

Основними видами маніпуляцій є: масові, особистісні та політичні. В межах даної статті розглянемо політичні маніпуляції як приховане управління політичною свідомістю та поведінкою людей з метою примусити їх до дії або бездіяльності всупереч їх власним інтересам. У цілому, способами політичного маніпулювання є: замовчування невигідної інформації, пряма підтасовка фактів, упереджена інтерпретація фактів, навішування ярликів для компрометації політиків, використання групових інтересів, надання сфальсифікованої інформації тощо [1].

Основними засобами політичної маніпуляції $\epsilon$ соціально-політичний міф - розповсюдження ідей, які сприймаються переважно на віру, без будь-якого критичного осмислення. У кожному суспільстві наявні міфи, які активно підтримуються правлячими колами, зокрема за допомогою 3МI. Загалом, міф як політичний інструмент дозволяє: перерозподілити владні ресурси, не зустрічаючи суттєвих перешкод із боку деморалізованого супротивника; докорінно зламати ситуацію, котра склалася на політичній арені, різко змінити громадську думку; отримати вихід до нових вагомих важелів влади. Міф забезпечує вихід до важелів управління масовою свідомістю за умови гострого дефіциту владних ресурсів. Тобто політичний міф містифікує (спотворює) політичну реальність, утворюючи у такий спосіб своєрідний структурний елемент свідомості - міфосвідомість, яка дозволяе спростити сприйняття складного світу політики завдяки цілісним і гармонійним уявленням заснованим на вірі, а не на логічному знанні, яке просякнуте внутрішніми суперечностями), іміджі (імідж є складним соціально-психологічним феноменом, який складається з раціональних (свідомих) та ірраціональних (підсвідомих і безсвідомих) психічних компонентів.

Наприклад, із крахом комуністичної системи почали формуватися такі соціально-політичні міфи: про капіталізм як «світле майбутнє»; про обов'язкові жертви у перехідний період; про правлячі кола і номенклатуру як уособлення демократів та реформаторів.

Безперечно, особливого значення маніпуляція набуває 3 удосконаленням інформаційних технологій, які суттєво розширюють спектр за $\neg$ стосування маніпулятивних стратегій і тактик. Розвиток і посилення ролі засобів масової комунікації дають підстави говорити про такі явища, як «медіа-свідомість», «четверта влада», «глобальне інформаційне суспільство», «світ симулянтів», тощо, що в свою чергу породжують явище маніпуляції. Стрімке поширення комп'ютерних технологій та мас-медіа призвело до виникнення феномену «кліпової», «комп'ютерної свідомості», яка поглиблює небажання більшості сучасних людей вдумуватися в процеси, які відбуваються, осмислювати реальність, що і приводить до ії краху. При цьому політичні еліти, володіючи владою, намагаються ефективно впливати на свідомість суспільства і роблять все можливе для того, щоб мати контроль над засобами масової інформації, які забезпечують доступ до різного роду інформації і практично замінили реальний світ політичних подій світом інформації, що постійно змінюється. Безсумнівно, ті, хто контролюють засоби масової інформації, контролюють таким чином і суспільну свідомість, отримують важливий політичний ресурс для реалізації своїх інтересів.

На сьогодні використовуються різні форми, способи та види маніпулювання через засоби масової інформації - прес-конференція, конференція, презентація, прес-тур, публікації в засобах масової інформації (цікаві статті, кейси-історії, оглядові статті, інтерв'ю), поширення пліток, вплив телебачення і радіо, мережі Інтернет.

У контексті вищезазначеного підкреслимо, що графічні засоби організації тексту сприяють його чіткій візуалізації та розставляють акценти повідомлення, підсилюючи його певні частини. 
Ці засоби можуть використовуватись окремо або в поєднанні $з$ іконічними засобами, підсилюючи маніпулятивний потенціал вербальної частини повідомлення. Зображення, що супроводжують текст, посилюють вплив вербальної аргументації завдяки добору іконічних елементів, що відповідає загальній маніпулятивній інтенції адресанта. Цьому також сприяють кольорові виокремлення, які привертають увагу до повідомлення та через властивості кольорів певним чином впливати на психіку людини налаштовують іiі на конкретне емоційне сприйняття інформації.

Так, засоби масової інформації використовують мову жестів як засіб маніпулювання свідомістю адресата, розміщуючи фотографії, яким притаманне певне оцінне значення невербальної поведінки об'єкта (наприклад, усмішка, відкриті долоні, стиснуті кулаки). Як правило, невербальні елементи підтверджують оцінку, що міститься у вербальній частині повідомлення, роблячи iํ більш ефективною.

Визначимо технології маніпулювання свідомістю, які використовують сучасні засоби масової інформації. Перш за все, це анонімний авторитет. Цей прийом введення в оману відноситься до так званої «сірої пропаганди». Давно доведено, що одним 3 ефективних методів впливу $є$ звернення до авторитету. Авторитет, до якого звертаються, може бути релігійною чи вагомою політичною фігурою, діячем науки тощо [5].

Голодовка. Ефективний прийом емоційного впливу на електорат і психологічного тиску на владу. Підбирається група добре оплачуваних молодих людей із міцним здоров'ям, які, нічим не ризикуючи, організують «курс лікувального голодування» в якому-небудь публічному місці. Навкруг цього засоби масової інформації здіймають неймовірний шум. При цьому постійно звучать звинувачення в нелюдяності режиму, організації або конкретної особи. Влада вимушені реагувати на вимоги, що висуваються «борцями».

Буденна розповідь. Якщо потрібно «привчити» людей до насильства, крові, убивств, усякого роду лиходійств, то щодня в засобах масової інформації повідомляється про найтяжчі з них. Через декілька тижнів такої обробки населення перестає реагувати на найжахливіші злочини і масові вбивства, що відбуваються в суспільстві (тобто наступає психологічний ефект звикання).

Такий прийом дозволяє ЗМІ зберегти ілюзію об'єктивного висвітлення подій, але, в той же час, девальвує значимість того, що відбулося, створює у масової аудиторії уявлення про дану подію як про щось малозначне, що не потребує особливої уваги і тим більше суспільної оцінки.

Тримай злодія. Цей прийом використовується для дискредитації, коли винні, відчуваючи поразку, першими піднімають крик і направляють гнів народу в інший бік. Цим прийомом часто користуються так звані «правозахисники», завданням яких є дезорганізація громадськості.

Емоційний резонанс. Спосіб створення у широкої аудиторії певного настрою 3 одночасною передачею їм пропагандистської інформації. Він дозволяє зняти психологічний захист, який на розумовому рівні вибудовує людина, свідомо намагаючись захиститися від пропагандистського або рекламного «промивання мозку». I якщо пропагандистський вплив на людину відбувається на емоційному рівні, поза ії свідомим контролем, ніякі раціональні контраргументи в цьому випадку не спрацьовують.

Набридлива похвала. Використовується для боротьби 3 опонентом, безперервно доречно вихваляючи його і недоречно показуючи незвичайні здібності, постійно тримаючи на слуху його ім'я, явно перебільшуючи його здібності. Дуже швидко це всім набридає і одне ім'я цієї людини викликає роздратування. Авторів такого заходу важко викрити в навмисній дискредитації, оскільки формально вони докладають зусилля тільки для похвали.

Під час виборів метод нерідко застосовується для створення «інформаційного шуму», коли за потоком другорядних повідомлень потрібно приховати якусь важливу подію чи проблему.

Ефект бумеранга. Це ті граблі, на які регулярно наступають можновладні угруповання. При організації тотального цькування свого опонента, вони «забивають» його до такої міри, що в результаті він починає викликати жалість і симпатію у широкої аудиторії. Те ж саме трапляється, коли влада вирішує боротися 3 поширеними в суспільстві негативними чутками - довіра до чуток тільки підсилюється.

Ефект бумеранга може мати і протилежну дію. Так, перенасиченість ефіру рекламою того або іншого кандидата починає викликати роздратування аудиторії.

Інформаційна блокада. Позбавити противника можливості публічно розкрити свою позицію одне з головних завдань пропагандистської війни.

Інформаційна блокада завжди тісно пов'язана 3 інформаційним домінуванням. До них вдаються як під час збройного конфлікту, так і за мирного часу (під час виборів). Заангажовані засоби масо- 
вої інформації створюють інформаційний ажіотаж тільки навколо свого кандидата. При цьому його опонент повністю позбавляється можливості розкрити свою позицію та дати відповідь на випади в свою адресу.

Ефект ореолу. Базується на підступній психологічній властивості - людській схильності мислити. Складається 3 двох поширених стереотипів-помилок [4].

1. «Поряд - значить разом». Знаходження поряд зі знаменитою або високопоставленою людиною дещо підвищує статус в очах оточуючих. Невипадково ті, хто зображений на фото поряд із відомими людьми, із задоволенням демонструють ці фотографії всім друзям і знайомим.

2. Другий стереотип полягає в тому, що людину, яка досягла вагомих успіхів у конкретній області, вважають здатною на більше і в інших справах. Численні факти доводять, що це всього лише поширена помилка. $€$ безліч прикладів, коли люди, які блискуче роблять одну справу, в усьому іншому виявляються абсолютно безпорадними.

Ефект присутності. Включає низку трюків, які імітують реальність, їх використовують при «репортажах із місця бою» та в кримінальній хроніці, фабрикуючи заднім числом зйомку «реального» затримання бандитів чи автокатастрофи. Ілюзію «бойової обстановки» створюють, наприклад, різкими рухами камери та порушенням її фокусу. При цьому все виглядає так, ніби оператор у страшному хвилюванні, під вогнем знімає реальність.

Ілюзія достовірності надає сильного емоційного впливу і створює відчуття автентичності подій, ніхто не підозрює, що це лише дешевий трюк.

Використання медіаторів. Дана техніка грунтується на двох постулатах. По-перше, встановлено, що більшого ефекту на формування думки 3 якого-небудь питання у «середньостатистичної людини» досягають не масовані пропагандистські кампанії в 3MI, а міфи, чутки і плітки, які циркулюють в суспільстві. Другий постулат витікає 3 першого: ефективний інформаційний вплив на людину здійснюється не безпосередньо від засобів масової комунікації, а через значущих для неї, знайомих їй авторитетних людей («лідерів думки») - трансляторів думок і чуток.

По-друге, це «контрастуючі слова» для того, щоб охарактеризувати опонента в негативному ключі [3].

Зворотний зв'язок. Сучасними засобами масової інформації широко практикуються способи «зворотного зв'язку» в різних формах: дзвінки в студію під час прямого ефіру, вибір по телефону варіанта відповіді на поставлене питання тощо. Подібний «макіяж» покликаний створити у масової аудиторії ілюзію участі в інформаційному процесі.

Коментарі. Повідомлення про факт супроводжується інтерпретацією коментатора, який пропонує читачеві або глядачеві декілька варіантів пояснення. Від спритності коментатора залежить можливість зробити необхідний варіант найбільш правдоподібним.

Для цього зазвичай використовується декілька додаткових прийомів.

По-перше, включення в пропагандистські матеріали так званих «двосторонніх повідомлень», які ніби випереджають аргументи опонента і при умілій їх критиці сприяють створенню певного імунітету проти них.

По-друге, дозуються позитивні і негативні елементи. Для того, щоб позитивна оцінка виглядала більш правдоподібною до характеристики описуваної точки зору додається небагато критики.

По-третє, здійснюється підбір фактів посилення або ослаблення висловлювань. Висновки не входять у текст наведених повідомлень, їх повинні зробити ті, для кого призначена інформація.

По-четверте, відбувається оперування порівняльними матеріалами для посилення важливості, демонстрації тенденцій і масштабності подій.

Констатація факту. Бажаний стан речей подається засобами масової інформації як факт, що відбувся. Прийом використовується для створення відповідних настроїв у суспільстві. Розрахунок на те, що більшість людей мислить стереотипами: «Диму без вогню не буває», «Раз про це всі говорять - значить так воно і є».

У людини штучно створюється відчуття себе в меншості. В результаті вона стає безініціативною, віддаючи пріоритет тому, кого вона вважає представником «більшості».

Такого роду пропаганда зазвичай подається під виглядом новин або результатів соціологічних досліджень, впроваджуючи при цьому звичайну дезінформацію.

Помилкова аналогія. Звичним для більшості людей стилем мислення $€$ той стиль, який використовує логічні зв'язки «причина-наслідок». Логічний зв'язок «конкретна причина - конкретний наслідок», який мав місце коли-небудь, ми схильні екстраполювати і на інші об'єкти, що не мають ніякого стосунку до цього - тут і криється каверза.

Обхід із флангу. Полягає в дозованій передачі достовірних відомостей, точність яких наперед відома слухачам або читачам і може бути легко 
ними перевірена. До категорії такої «переконливої інформації» належать фактичні дані, наприклад, імена, назви вулиць, інші деталі, що є достовірними і в які «упаковуються» пропагандистські повідомлення [2].

Псевдосоціологічні опитування (коли під час ефіру глядачі голосують по телефону) частіше за все $є$ лише способом формування громадської думки, а не його реальним віддзеркаленням, тобто різновидом звичайної пропагандистської маніпуляції. Питання формулюються так, щоб створити в аудиторії «правильний погляд» на ту чи іншу проблему. Вони спрямовують хід наших роздумів у конкретному напрямі. «Ніколи не ставте питання, на яке не можна отримати ту відповідь, яка вам потрібна», - головний принцип подібних опитувань.

Різновидом зворотного зв'язку є різноманітні варіанти спілкування високопоставлених персон із «простим народом».

Відповідні телепрограми організовуються таким чином, ніби глава держави (або інша високопоставлена персона) спонтанно відповідає на питання, задані громадянами по телефону або через Інтернет. Кращий експромт - це раніше підготовлений експромт. Ця стара приказка згадується сама по собі, коли спостерігаєш, як черговий Гарант Конституції з недосяжною для простих смертних жвавістю і зв'язністю мови дуже вдало відповідає на декілька десятків досить непростих питань, що поступають за короткий час. Насправді він дає відповіді, що заздалегідь ретельно підготовлені його командою.

Відволікання уваги. Для будь-якого виду маніпуляції важливим завданням є придушення психологічного опору людини навіюванню. Тому будь-яка пропаганда повинна бути комбінацією розважального, інформаційного і переконливого компонентів. Виключно сильним відволікаючим впливом володіють безпрецедентні події (вбивства, катастрофи, терористичні акти, гучні скандали). Під їх прикриттям політики зазвичай поспішають провернути всі темні справи.

Політична реклама є невід'ємною частиною маніпуляційних технологій, яку суб' єкти політичного процесу використовують 3 метою впливу на громадську думку. Виконуючи інформаційну та пропагандистську функції, політична реклама впливає на зміст та якість соціальних цінностей, традицій і норм, які регулюють політичні відносини. Рівень та характер політичних знань, оцінок та дій громадян, на які вона здійснює вплив, визначає стан політичної культури у суспільстві [6].
У теперішніх умовах в інформаційно-комунікативних процесах використовуються не просто окремі прийоми, а спеціальні маніпулятивні технології. Всі вони, в основному, визначаються за аналогією із промисловими технологіями як сукупність прийомів, методів і засобів, використовуваних для досягнення конкретних цілей. Маніпулятивні технології формуються на основі певних сполучень цих елементів 3 урахуванням специфічних закономірностей їхньої взаємодії. При цьому важлива також послідовність і частота застосування прийомів маніпулювання при їхньому використанні в конкретних інформаційно-комунікативних ситуаціях.

Зауважимо, що технологіями маніпулювання свідомістю називають послідовну сукупність методів, прийомів і засобів маніпуляційного впливу, метою якого є спонукання суб'єкта до заздалегідь визначеного вирішення певного завдання. Грамотний вибір технологій дозволяе маніпулятору домагатися запланованих результатів шляхом формування в масовій свідомості найбільш прийнятних для себе суспільних та дієвих алгоритмів.

Існує досить великий набір методів та технологій маніпуляційного впливу, заснованих на психології сприйняття людини.

Говорячи про технології маніпуляційного впливу, слід враховувати, що розробка і здійснення технології маніпуляції реалізується поетапно. Найбільш істотними з них є планування впливу, збір інформації про об'єкт маніпуляції, вибір раціональних прийомів впливу, організація ситуації впливу, індикація ефективності проведеного впливу, корекція впливу (якщо він виявився неефективним).

Наприклад, технологія формування й поширення образів $є$ універсальною маніпулятивною технологією, яка широко й активно використовується в масових інформаційних процесах. Суть iï полягає в тому, що залежно від цілей і конкретних завдань маніпулятором формуються й поширюються заздалегідь «сконструйовані» образи конкретних осіб, організацій, ідей, програм тощо, які, як правило, неадекватно відбивають їх реальні найбільш важливі характеристики й таким чином дезорієнтують людей, на яких спрямований інформаційно-психологічний вплив.

У цьому контексті образ (імідж) - це таке відображення сприйманого явища, при якому його ракурс навмисне зміщається за допомогою акцентування уваги тільки на певних сторонах явища. Сформований образ світу дозволяє істотно спростити у суб'єкта шкалу його оцінок суспіль- 
но-політичних явищ на кшталт: «біле-чорне», «добре-погане», «добро-зло» тощо. Нав'язується образ, який складається із пропонованих кліше-шаблонів, що лежать в основі соціально-політичних орієнтирів суб'єктів. Він створюється шляхом цілеспрямованих або, у деяких випадках, спонтанних дій за допомогою маніпулювання імперативними установками на кшталт дихотомічного розподілу світу, використання «образу ворога», широкої пропаганди «самоочевидних» рішень (коли за «очевидні» видаються добре підтасовані факти) тощо [9].

Зазначимо, що формовані образи можна поділити на кілька типів: образ, в основу якого покладене домінуюче бажання основної маси; образ «чужого», який цілеспрямовано розробляється для використання в маніпулятивних технологіях; розмитий образ, що виключає деталізацію складових його елементів, так званий «корпоративний» образ; образ, сформований на основі нестачі потрібної інформації або її недорозуміння; образ, що не припускає створення цілісного сприйняття актуального явища або множинний образ тощо.

Формований образ слід розглядати як варіант стиску інформації, коли величезний обсяг відомостей згортається до обмеженого набору поширених символів, які активно використовуються при здійсненні маніпуляції. Взагалі, усяке маніпулювання пов'язане із цілеспрямованим перекручуванням інформації [8]. Подібне їі перетворення $\epsilon$ потужним інструментом при створенні маніпулятивних політичних технологій.

Найважливішою складовою частиною механізмів маніпулювання $є$ мікрополітичні технології. Політична історія i сучасні внутрішньополітичні i міжнародні процеси містять різноманітні приклади активного використання маніпулятивних політичних технологій, обумовлених прийомами політичної боротьби.

Під час демократичних реформ у політичній сфері почали з'являтися незнайомі раніше політичні поняття і явища: політична конкуренція, демократичні цінності, вільні вибори, багатопартійність, плюралізм, PR-технології тощо. До того ж політичні маніпуляції в Україні, особливо в період проведення виборчих кампаній, стають невід'ємною політичною складовою технології влади. В цілому, маніпуляція свідомістю під час виборчих кампаній це - система засобів ідеологічного і духовно-психологічного впливу на свідомість виборців, за умов приховування справжніх цілей і думок, з метою отримання підтримки певної політичної сили, що не лише спонукає осо- бу віддати свій голос за потрібного кандидата чи партію, а й примушує їі хотіти це зробити.

Ресурси специфічних методів у політичних кампаніях можна поділити на такі групи: адміністративні ресурси (залякування держслужбовців, фальсифікація виборів; маніпуляції 3 опонентом, антиреклама, контрпропаганда); психоманіпуляції (методи, що впливають на психічні структури виборців. Вони включають шокуючі повідомлення, обман, наклепи).

На сьогодні широко почали використовуватися методи дезінформації і втілення фантазій політтехнологів, які демонстрували великі успіхи у створенні девізів і слоганів контрпропаганди, вигадуванні образливих кличок, ярликів, анекдотів. До того ж активно використовується метод спотворення візуального образу на листівках та інформаційних матеріалах.

Досягнення управлінських цілей допускає сьогодні наявність цілого арсеналу технологічних маніпуляцій, що їх влада бере на озброєння для підтримки певного соціально-політичного ідеалу. Так, сама природна функція політики - керування свідомістю і поведінкою - легко може перерости в маніпулювання, особливо у тих випадках, коли керування внаслідок певних причин не може бути достатньою мірою раціоналізоване (наприклад, вирішення складного політичного завдання, не зовсім усвідомленого і самою владою, виникнення суперечливих і спірних ситуацій, неясність перспектив політичного розвитку, розкол суспільства, низький рівень суспільної самосвідомості тощо). У цьому випадку маніпулювання стає можливим, але тільки в межах, у яких воно не втрачає свого раціонального значення. Не випадкова тому в цій ситуації роль соціально-політичного ідеалу, що виявляється у гаслах, штампах, родових культурних стереотипах (ідеї неповторності нації, самобутності їі культурних традицій тощо).

Крім того, маніпулювання свідомістю електорату передбачає певний ступінь довіри суспільства до політичного лідера і по-суті стимулюється його довірою. Проте при виході за межі припустимого довіра легко переходить у віру, чи у недовіру. А довіра складає потужний ірраціональний резерв політики, а також утворює при цьому не менш значний потенціал соціально-політичного ідеалу. Те, що цей потенціал не тільки не шкодить політиці, але й охоче використовується владою, не викликає сумніву. А успішне використання маніпуляції свідомістю, що належним чином впливає на вибір електорату, може означати фінансову та інтелектуальну перевагу [10]. 
Одним із найбільш важливих та впливових інструментів проведення політичних кампаній $\epsilon$ маніпулювання інформацією, яке містить у собі ряд прийомів. Наприклад, повідомляється гігантська кількість інформації, основну частину якої становлять абстрактні міркування, непотрібні деталі, різні дрібниці тощо. У результаті виборець не може розібратися в суті проблеми.

Ще одним прийомом $є$ дозування інформації - дається тільки частина повідомлень, а решта ретельно приховуються. Це призводить до того, що реальна картина спотворюється в той чи інший бік або взагалі стає незрозумілою. Змішування реальних фактів із усілякими припущеннями, гіпотезами, чутками. В результаті стає неможливим відрізнити правду від вигадки.

Зволікання часу. Цей спосіб зводиться до того, щоб під різними приводами відтягувати оприлюднення дійсно важливих повідомлень до того моменту, коли буде вже пізно щось змінити.

Зворотний удар. Суть цього способу в тому, що вигадану (природно, вигідну для себе) версію тих чи інших подій через підставних осіб поширюють в органах 3MI. Преса, а за нею електорат, звичайно, повторює цю версію, тому що вона вважається «об’ єктивнішою».

Своєчасна неправда. Цей спосіб полягає в повідомленні зовсім брехливої, але надзвичайно очікуваної в даний момент («гарячої») інформації. Чим більше зміст повідомлення відповідає настроям об'єкта, тим ефективніший результат обману. Потім обман розкривається, але за цей час гострота ситуації спадає або процес набуває необоротного характеру [7].

Висновки. Таким чином, технології маніпулювання передбачають використання багатого арсеналу конкретних методів впливу на свідомість людей. До них належать пряме підтасовування фактів, замовчування небажа $\neg$ ної інформації, поширення брехні і наклепу, а також більш тонкі, рафіновані засоби, наприклад, напівправда (коли 3 метою забезпечення довіри аудиторії об'єктивно і докладно висвітлюються конкретні, малозначущі факти й одночасно замовчуються більш важливі або ж подається хибна інтерпретація подій).

\section{БІБІЛІОГРАФІЧНІ ПОСИЛАННЯ}

1. Анохин М. Политические технологи / М. Анохин // Вестник Российского университета дружбы народов. Сер.: Политология. - 2015. - № 2. - С. 101-104.

2. Бузин А. Административные избирательные технологии и борьба с ними / А. Бузин. - М.: Центр «Панорама», 2007. $-271 \mathrm{c}$.

3. Варій М. Політико-психологічні передвиборчі та виборчі технології / М. Варій. - Київ, 2016. - 400 с.

4. Ганжуров Ю. Політична реклама чи політична пропаганда? / Ю. Ганжуров // Віче. - 2016. - № 9. - С. 16-18.

5. Ганжуров Ю. Політична реклама як засіб формування парламентської еліти / Ю. Ганжуров // Політичний менеджмент. - 2017. - Спец. вип. - С. 33-40.

6. Головатий М. Мистецтво здобувати владу / М. Головий // Політичний менеджмент. - 2014. - № 1. - С. 49-58.

7. Каплан Ю. Політичні технології в Україні: особливості адміністративного ресурсу президентських виборчих кампаній / Ю. Каплан // Віче. - 2016. - № 2. - С. 4-14.

8. Климанська Л. Соціально-комунікативні технології в політиці: таємниці політичної «кухні» / Л. Климанська. Львів: Видавництво Львівської політехніки, 2017. - 332 с.

9. Кочубей Л. Виборчі технології: політологічний аналіз (на прикладі виборів до парламенту сучасної України): монографія. - Київ: Вид-во «Юридична думка», 2016. - 280 с.

10. Кочубей Л. Виборчі технології як механізм політичного результату / Л. Кочубей // Людина і політика. - 2015. № 4. - С. 56-62.

\section{REFERENCES}

1. Anokhin, M. (2015). Politicheskie tehnologi [Political Technologies]. Vestnyk Rossyjskoho unyversyteta druzhby narodov. Politologija, 2, 101-104 [in Russian].

2. Buzin, A. (2007) Admynystratyvnye yzbyratel'nye tekhnolohyy y bor'ba s nymy [Administrative Election Technologies and Their Combating]. Moscow: Centr «Panorama» [in Russian].

3. Vary M. (2016) Polityko-psykholohichni peredvyborchi ta vyborchi tekhnolohii [Political and psychological preelection and electoral technologies]. Kyiv [in Ukrainian].

4. Ganzhurov, Y. (2016). Politychna reklama chy politychna propahanda? [Political advertising or political propaganda?]. Viche, 9, 16-18 [in Ukrainian]. 
5. Ganzhurov, Y. (2017). Politychna reklama yak zasib formuvannia parlamentskoi elity [Political advertising as a means of forming a parliamentary elite]. Politychnyj menedzhment, (pp. 33-40) [in Ukrainian].

6. Holovaty, M. (2014). Mystetstvo zdobuvaty vladu [Art to acquire power]. Politychnyj menedzhment, 1, 49-58 [in Ukrainian]. 7. Kaplan. Y. (2016). Politychni tekhnolohii v Ukraini: osoblyvosti administratyvnoho resursu prezydentskykh vyborchykh kampanii [Political Technologies in Ukraine: Features of the Administrative Resource of Presidential Election Campaigns]. Viche, 2, 4-14 [in Ukrainian].

8. Klimanska, L. (2017) Sotsial'no-komunikatyvni tekhnolohii v politytsi: taiemnytsi politychnoi «kukhni» [Social and communicative technologies in politics: the secrets of the political «kitchen»]. Lviv: Vydavnytstvo Lvivskoi politekhniky [in Ukrainian].

9. Kochubei, L. (2016) Vyborchi tekhnolohii: politolohichnyj analiz (na prykladi vyboriv do parlamentu suchasnoi Ukrainy) [Election technologies: political analysis (on the example of elections to the parliament of contemporary Ukraine)]. Kyiv: Vyd-vo «Iurydychna dumka» [in Ukrainian].

10. Kochubei, L. (2015). Vyborchi tekhnolohii yak mekhanizm politychnoho rezultatu [Election technologies as a mechanism of political result]. Ekonomika Ukrainy, 4, 56- 62 [in Ukrainian].

\section{Костельнюк Марина Михайлівна}

Старший викладач кафедри соціології

Чорноморський національний університет імені П. Могили

54003, м. Миколаїв, вул. 68 Десантників, 10

\section{Kostelniuk Marina}

Senior Lecturer, Department of Sociology

Petro Mohyla Black Sea National University

10, 68 Desantnykiv str., Mykolaiv, 54003, Ukraine

Email: kostelnyuk.marina@gmail.com

Цитування: Костельнюк М. М. Маніпуляційні технології в політичних процесах: термінологічний інструментарій / М. М. Костельнюк // Науково-теоретичний альманах «Грані». - 2018. - Т. 21. - № 5. С. $123-132$.

Citation: Kostelniuk, M.M. (2018). Manipuliatsiini tekhnolohii v politychnykh protsesakh: terminolohichnyi instrumentarii [Manipulation technologies in political processes: terminological tools]. Scientific and theoretical almanac «Grani», 21(5), 123-132. 